\title{
Impact of positive pleural lavage cytology on survival in patients having lung resection for non-small-cell lung cancer: An international individual patient data meta-analysis
}

\author{
International Pleural Lavage Cytology Collaborators*
}

\begin{abstract}
Objectives: Pleural lavage cytology is the microscopic study of cells obtained from saline instilled into and retrieved from the chest during surgery for non-small-cell lung cancer. The aims of this study were to collate multiinstitutional individual patient data for meta-analysis to determine independence as a prognostic marker and to characterize the impact of positive results on stage-adjusted survival.
\end{abstract}

\begin{abstract}
Methods: We identified 31 publications from 22 centers/research groups that performed pleural lavage cytology during surgery for non-small-cell lung cancer and invited submission of individual patient data. Actuarial survival was calculated using Kaplan-Meier methods, and comparisons were performed using the log-rank test. Cox proportional hazards regression was used to ascertain the covariates associated with survival.

Results: By January 1, 2008, submissions were received internationally from 11 centers with individual data from 8763 patients. In total, $511(5.8 \%)$ patients had a positive pleural lavage cytology result, and this was shown to be an independent predictor of adverse survival associated with a hazard ratio of $1.465(1.290-1.665 ; P<.001)$ compared with a reference hazard ratio of 1 for a negative result. On statistical modeling, the best adjustment for patients with a positive pleural lavage cytology result was a single increase in the T category assigned to the case, up to a maximum of T4. Correction for differences in survival were obtained in stages IB $(P=.315)$ and IIB $(P=.453)$, with a degree of correction in stage IIIA $(P=.07)$.
\end{abstract}

Conclusions: Pleural lavage cytology should be considered in all patients with non-small-cell lung cancer suitable for resection. A positive result is an independent predictor of adverse survival, and the impact on survival suggests that it may be appropriate to upstage patients by 1 T category. (J Thorac Cardiovasc Surg 2010;139:1441-6)

Pleural lavage cytology (PLC) is the microscopic study of cells obtained from saline instilled into and retrieved from the chest cavity (in patients without preoperative pleural effusion) during surgery for non-small-cell lung cancer. The solution is aspirated, and cytologic analysis is performed to screen for malignant cells. Results from this procedure

\footnotetext{
* Authors: Eric Lim, Rachel Clough, Peter Goldstraw (The Royal Brompton Hospital, London, United Kingdom); Lyn Edmonds (Papworth Hospital, Cambridge, United Kingdom); Keiju Aokage, Junji Yoshida, Kanji Nagai (National Cancer Centre East, Chiba, Japan); Yasushi Shintani, Mitsunori Ohta, Meinoshin Okumura, Teruo Iwasaki, Tsutomu Yasumitsu (Osaka Prefectural Medical Center for Respiratory and Allergic Diseases, Osaka, Japan); Morihito Okada, Takeshi Mimura, Noriaki Tsubota (Hyogo Cancer Centre, Akashi, Japan); Tatsuo Nakagawa, Norihito Okumura (Kurashiki Central Hospital, Okayama, Japan); Yukitoshi Satoh, Sakae Okumura, Ken Nakagawa (Cancer Institute Hospital, Tokyo Japan); Masahiko Higashiyama, Ken Kodama (Osaka Medical Centre for Cancer and Cardiovascular Diseases, Osaka, Japan); Marc Riquet (Hopital European Georges Pompidou, Paris, France); Giovanni Vicidomini, Mario Santini (Second University of Naples, Naples, Italy); Christophoros Kotoulas (Chest Diseases Hospital, Athens, Greece); Jeng-Yuan Hsu, Chih-Yi Chen (Taiching Veterans General Hospital, Taichung, Taiwan).

Disclosures: None.

Received for publication Nov 3, 2008; revisions received April 24, 2009; accepted for publication May 16, 2009; available ahead of print Nov 25, 2009.

Address for reprints: Eric Lim, MB, ChB, MD, MSc, FRCS(C-Th), Imperial College and The Academic Division of Thoracic Surgery, The Royal Brompton Hospital, Sydney Street, London SW3 6NP, United Kingdom (E-mail: e.lim@rbht.nhs.uk). 0022-5223/\$36.00

Copyright (c) 2010 by The American Association for Thoracic Surgery doi:10.1016/j.jtcvs.2009.05.048
}

have been published from Japan as early as $1989,{ }^{1}$ and internationally, an increasing number of centers have adopted this practice.

The frequency of positive results in the literature varies according to amount of solution used, timing of the procedure, and the center, but in general is less than $10 \%$ in the larger published series. Because the positive pickup rate is low, it is difficult for any single center alone to accumulate sufficient patient numbers for detailed study. As a result, its role as an independent predictor of prognosis has not been firmly established ${ }^{2,3}$ and neither is the lung cancer community certain where to best place patients with positive results in relation to International Union Against Cancer (UICC)/American Joint Committee on Cancer (AJCC) stage-adjusted survival.

The aims of this study were to collate individual patient data from centers that have performed PLC to determine independence as a prognostic marker and to characterize the impact of a positive result on stage-adjusted survival.

\section{METHODS}

A literature search was conducted by a professional medical librarian to identify publications on PLC (the full search strategy is available from Lyn Edmonds on request). From each publication, the authors were contacted by 


\section{Abbreviations and Acronyms \\ AJCC $=$ American Joint Committee on Cancer \\ PLC = pleural lavage cytology \\ UICC $=$ International Union Against Cancer}

E-mail or telephone or in person and invited to contribute data from their respective centers. Authors who responded were issued a data dictionary, and submissions were collated electronically in the specified standardized format. Staging was requested to follow the 6th UICC TNM Classification of Malignant Disease. ${ }^{4}$

\section{Statistical Analyses}

Continuous variables are expressed as means with standard deviations or median with interquartile ranges as appropriate to the data distribution. Nominal and categorical variables are expressed as frequency counts with percentages (\%). Actuarial survival was calculated using Kaplan-Meier methods, and comparisons were performed using the log-rank test. Cox proportional hazards regression was used to ascertain the covariates associated with survival. Exploratory models were undertaken to determine the effect of upstaging of patients with positive PLC, including fixed and variable T-category assignment and stage groupings, compared with their peers at a higher stage.

Statistical analyses were performed using R 2.6.0 (R core development team, Vienna, Austria) and Stata 9.2 (StataCorp, College Station, Tex). There was no funding associated with this project.

\section{RESULTS}

From 345 abstracts, we identified 31 publications ${ }^{1-3,5-32}$ from 22 centers/research groups that performed PLC dur- ing surgery for non-small-cell lung cancer. All lead authors from the identified centers or research groups were contacted by E-mail or telephone or in person. By the deadline of January 1, 2008, submissions were received internationally from 11 centers with individual data from 8763 patients. The mean age (standard deviation) of the cohort was 64 (10) years, with the majority being male $(66 \%)$. The demographic and follow-up details from the 11 centers and entire cohort are summarized in Table 1. The pathologic $\mathrm{T}, \mathrm{N}$, and $\mathrm{M}$ categories are summarized in Table 2.

In total, $511(5.8 \%)$ patients were documented with positive PLC (evaluated on light microscopy), and the staging characteristics in 477 patients with complete staging information were 29 (6.1) in IA, 122 (25.6) in IB, 7 (1.5) in IIA, 92 (19.3) in IIB, 112 (23.4) in IIIA, 84 (17.6) in IIIB, and 31 (6.5) in IV, respectively.

\section{Survival}

At a median follow-up time of $3.3(1.3-5.8)$ years, followup was complete in 8213 patients $(94 \%)$ with $3441(39 \%)$ deaths. On multivariable Cox regression analysis (Table 3), positive PLC status was identified as an independent predictor of adverse survival, associated with a hazard ratio of 1.465 (1.290-1.665; $P<.001)$. Increasing age, male gender, increasing UICC/AJCC staging categories of $\mathrm{pT}, \mathrm{pN}$, and $\mathrm{M}$ status were all independent predictors of adverse survival $(P<.001)$. In addition, despite inclusion in the $\mathrm{T}$ categories, tumor size $(P<.001)$ and breeching of the visceral

TABLE 1. Demographic and follow-up details

\begin{tabular}{|c|c|c|c|c|c|c|c|c|}
\hline Centre & Institution & Location & Number, $\mathbf{n}$ & $\begin{array}{c}\text { Mean } \\
\text { age }(\mathrm{SD})\end{array}$ & $\begin{array}{c}\text { Males, } \\
\text { n }(\%)\end{array}$ & $\begin{array}{c}\text { Positive } \\
\text { PLC, n (\%) }\end{array}$ & $\begin{array}{c}\text { Median } \\
\text { follow up, } \mathbf{y}(\mathrm{IQR})\end{array}$ & $\begin{array}{c}\text { Deaths, } \\
\text { n }(\%) \\
\end{array}$ \\
\hline 1 & $\begin{array}{l}\text { National Cancer } \\
\text { Center Hospital East }\end{array}$ & Chiba, Japan & 2950 & $65(10)$ & $1866(63)$ & $117(4.0)$ & $3.0(1.4-6.1)$ & $982(33)$ \\
\hline 2 & $\begin{array}{l}\text { Osaka Medical Centre } \\
\text { for Cancer and } \\
\text { Cardiovascular Diseases }\end{array}$ & Osaka, Japan & 507 & $63(9)$ & $363(72)$ & $73(14.4)$ & $4.5(2.1-6.4)$ & $249(49)$ \\
\hline 3 & $\begin{array}{l}\text { Taichung Veterans } \\
\text { General Hospital }\end{array}$ & Taichung, Taiwan & 36 & $64(8)$ & $29(81)$ & $15(41.7)$ & $1.5(0.4-5.2)$ & $28(78)$ \\
\hline 4 & $\begin{array}{l}\text { The Royal Brompton } \\
\text { Hospital }\end{array}$ & London, UK & 292 & $64(10)$ & $196(67)$ & $13(4.5)$ & $1.25(0.1-3.3)$ & $94(32)$ \\
\hline 5 & $\begin{array}{l}\text { Hopital European } \\
\text { Georges Pompidou }\end{array}$ & Paris, France & 194 & $62(12)$ & $140(72)$ & $24(12.3)$ & $2.7(1.3-3.7)$ & $84(43)$ \\
\hline 6 & $\begin{array}{c}\text { Osaka Prefectural Medical } \\
\text { Center for Respiratory } \\
\text { and Allergic Diseases }\end{array}$ & Osaka, Japan & 1522 & $64(10)$ & $1081(71)$ & $92(6.0)$ & $2.3(1.0-5.5)$ & $839(55)$ \\
\hline 7 & Kurashiki Central Hospital & Okayama, Japan & 1025 & $67(10)$ & $627(61)$ & $45(4.3)$ & $2.2(0.8-4.8)$ & $253(25)$ \\
\hline 8 & Hyogo Cancer Centre & Akashi, Japan & 1192 & $64(10)$ & $833(70)$ & $52(4.3)$ & $4.5(2.4-6.4)$ & $517(43)$ \\
\hline 9 & Cancer Institute Hospital & Tokyo, Japan & 853 & $63(10)$ & $500(59)$ & $41(4.8)$ & $4.4(2.9-6.2)$ & $272(32)$ \\
\hline 10 & Second University of Naples & Naples, Italy & 107 & $65(9)$ & $97(91)$ & $31(29.0)$ & $4.9(1.9-5.8)$ & $43(40)$ \\
\hline 11 & Chest Diseases Hospital & Athens, Greece & 85 & $60(8)$ & $77(91)$ & $8(9.4)$ & $3.4(1.4-4.9)$ & $80(94)$ \\
\hline Total & & & 8763 & $64(10)$ & $5809(66)$ & $511(5.8)$ & $3.3(1.3-5.8)$ & $3441(39)$ \\
\hline
\end{tabular}

$I Q R$, Interquartile range; $P L C$, pleural lavage cytology; $S D$, standard deviation. 


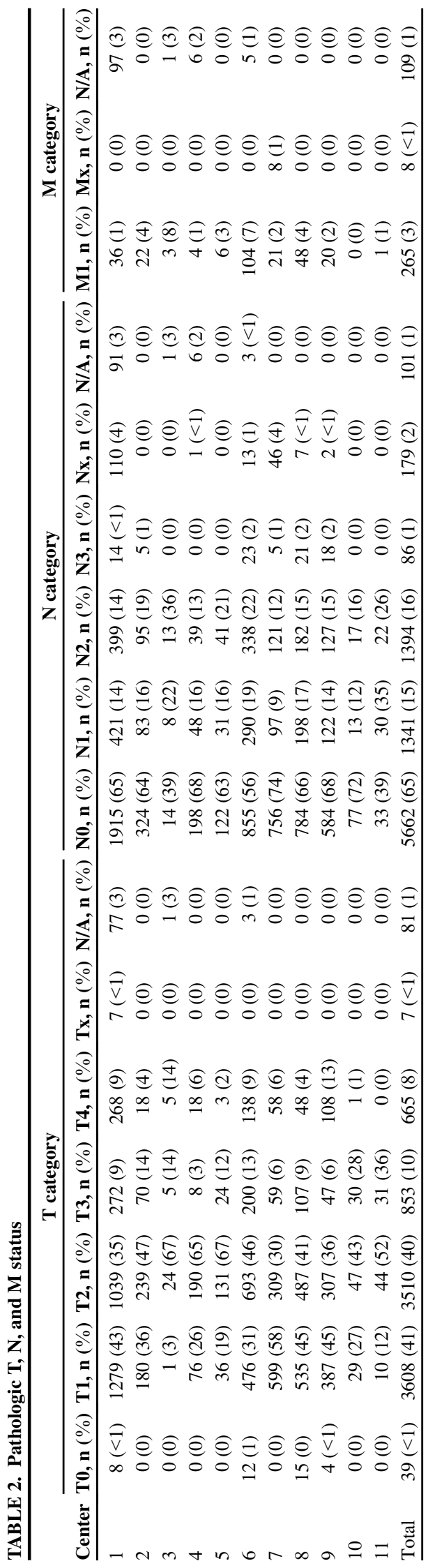

TABLE 3. Multivariable predictors of survival

\begin{tabular}{lccc}
\hline \multicolumn{1}{c}{ Covariate } & $\begin{array}{c}\text { Hazard } \\
\text { ratio }\end{array}$ & $\begin{array}{c}\mathbf{9 5} \% \text { confidence } \\
\text { interval }\end{array}$ & $\boldsymbol{P}$ value \\
\hline Positive lavage cytology & 1.465 & $1.290-1.665$ & $<.001$ \\
Age, per year & 1.023 & $1.019-1.027$ & $<.001$ \\
Female gender & 0.683 & $0.625-0.746$ & $<.001$ \\
pT category & & & \\
T1 & 1.000 & N/A & N/A \\
T2 & 1.422 & $1.277-1.583$ & $<.001$ \\
T3 & 1.340 & $1.116-1.610$ & .002 \\
T4 & 1.511 & $1.292-1.767$ & $<.001$ \\
pN category & & & \\
N0 & 1.000 & N/A & N/A \\
N1 & 1.897 & $1.723-2.088$ & $<.001$ \\
N2 & 3.133 & $2.864-3.427$ & $<.001$ \\
N3 & 4.758 & $3.680-6.153$ & $<.001$ \\
M1 status & 2.169 & $1.854-2.539$ & $<.001$ \\
Size of primary & 1.091 & $1.069-1.113$ & $<.001$ \\
$\quad$ tumor, cm & & & \\
Visceral pleural invasion & 1.289 & $1.183-1.404$ & $<.001$ \\
Parietal pleural invasion & 1.344 & $1.150-1.571$ & $<.001$ \\
\hline
\end{tabular}

$(P<.001)$ and parietal pleura $(P<.001)$ remained stageindependent predictors of adverse survival.

The overall 1- and 5-year survivals of the 511 patients who were PLC-positive were $80 \%$ and $31 \%$, respectively. Stage for stage, patients with positive PLC results had poorer survival compared with their peers with a negative result (Figure 1, $A-C$ ). When overall survival was plotted for stage groupings I to III, patients with positive PLC result had similar overall survival to patients in UICC/AJCC stage III (Figure 1,D).

Using exploratory statistical modeling, the best adjustment for patients with a positive PLC result was to increase the $\mathrm{T}$ category assigned by a single numerical category (upstage). This had the effect of upstaging patients into designated groups and retaining the independent effects of nodal status on patients who were PLC-positive. The differences in adjusted survival by increasing the $\mathrm{T}$ stage by 1 category for patients who were PLC-positive (up to a maximum of T4 status) are presented in Figures 2 and 3 for stages IB, IIB, IIIA, and IIIB. The results were not presented for stages IA and IIA, as no comparative group remains when patients in $\mathrm{T} 1$ who were PLC-positive are reassigned to T2. Good correction is visible in stages I to II, and the differences are somewhat reduced in stage IIIB. No correction is present in stage IIIB as the T4 designation remains unaltered.

\section{DISCUSSION}

Although a number of studies have reported positive PLC result as a predictor of poor prognosis, there have been conflicting opinions if it is independent to UICC/AJCC stage. ${ }^{2}$ A principle difficulty in evaluating prognostic independence on multivariable analyses is the relatively small number of 
Stage I survival

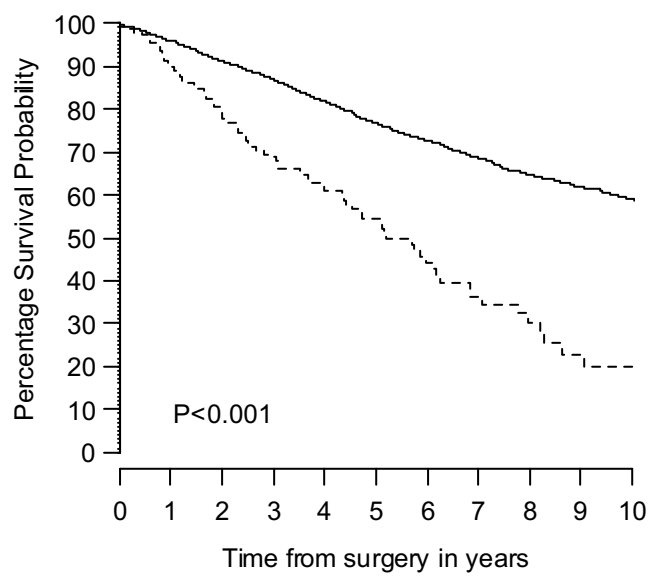

Stage III survival

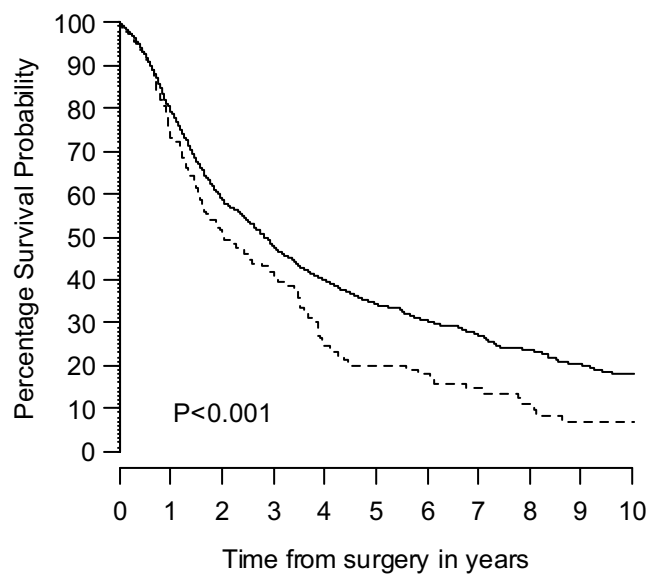

Stage II survival

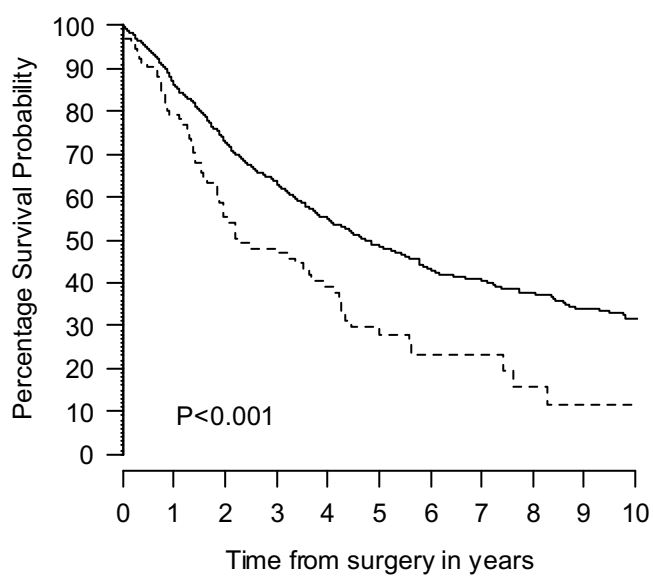

Stage I-III versus PLC positive survival

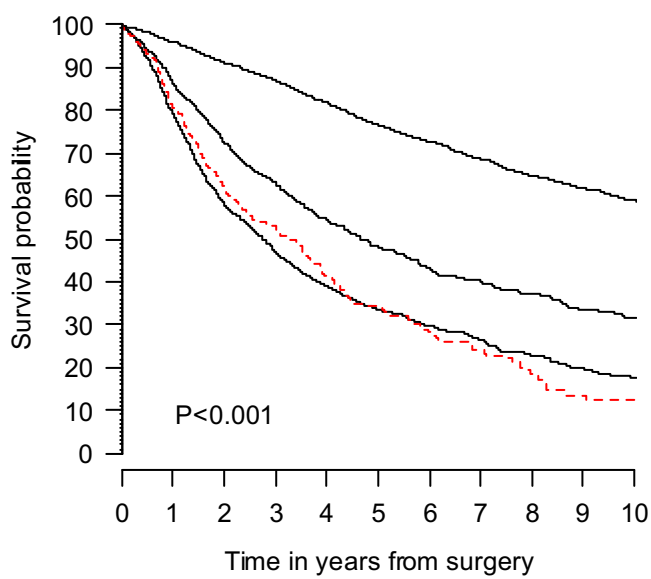

FIGURE 1. Overall survival by stage and pleural lavage cytology $(P L C)$ status. Solid lines are patients with negative PLC; dashed lines are patients with positive PLC.

patients with a positive result. To address this problem, a collaborative effort was undertaken by 11 centers from around the world contributing individual data from over 8700 patients.

The results of our study confirm the independence of positive PLC as an adverse prognostic predictor in patients (without preoperative malignant effusion) deemed suitable for lung resection for non-small-cell lung cancer. The effect is the upstaging of patients by $1 \mathrm{~T}$ category (up to a maximum of T4). Although patients with T4 disease had poorer survival associated with a positive PLC status, this remained better than the M1a designation of the International Association for the Study of Lung Cancer proposals for stage grouping in the 7th edition of TNM in lung cancer. ${ }^{33}$

PLC is inexpensive and simple to perform and does not require specialized equipment or facilities for analysis. Techniques, however, differ from center to center, and there is a need to standardize this practice internationally, to minimize differences in the positive results that may arise from differences in technique. We recommend $100 \mathrm{~mL}$ of saline irrigated over the lung surface immediately after thoracotomy and prior to lung resection. The saline is aspirated and the sample sent for cytologic screening for malignant cells. The UICC recommends that cytologic results of pleural and peritoneal washings be considered separate to the classification of isolated tumor cells and micrometastasis. In addition, identification of patients with positive PLC results can be recorded with the suffix of $(\mathrm{cy}+){ }^{34}$

The effect of upstaging patients with early stage disease will shift a proportion of patients from stage I to II, the threshold for consideration of postoperative chemotherapy. It would be ideal for further trials to be conducted to specifically evaluate the utility of postoperative chemotherapy in the setting of positive PLC status. In the absence of such evidence, the implications for the change in stage and the potential benefits for adjuvant chemotherapy should be carefully considered.

The inferences from this work were based on the availability of the submitted data and on the assumption that 

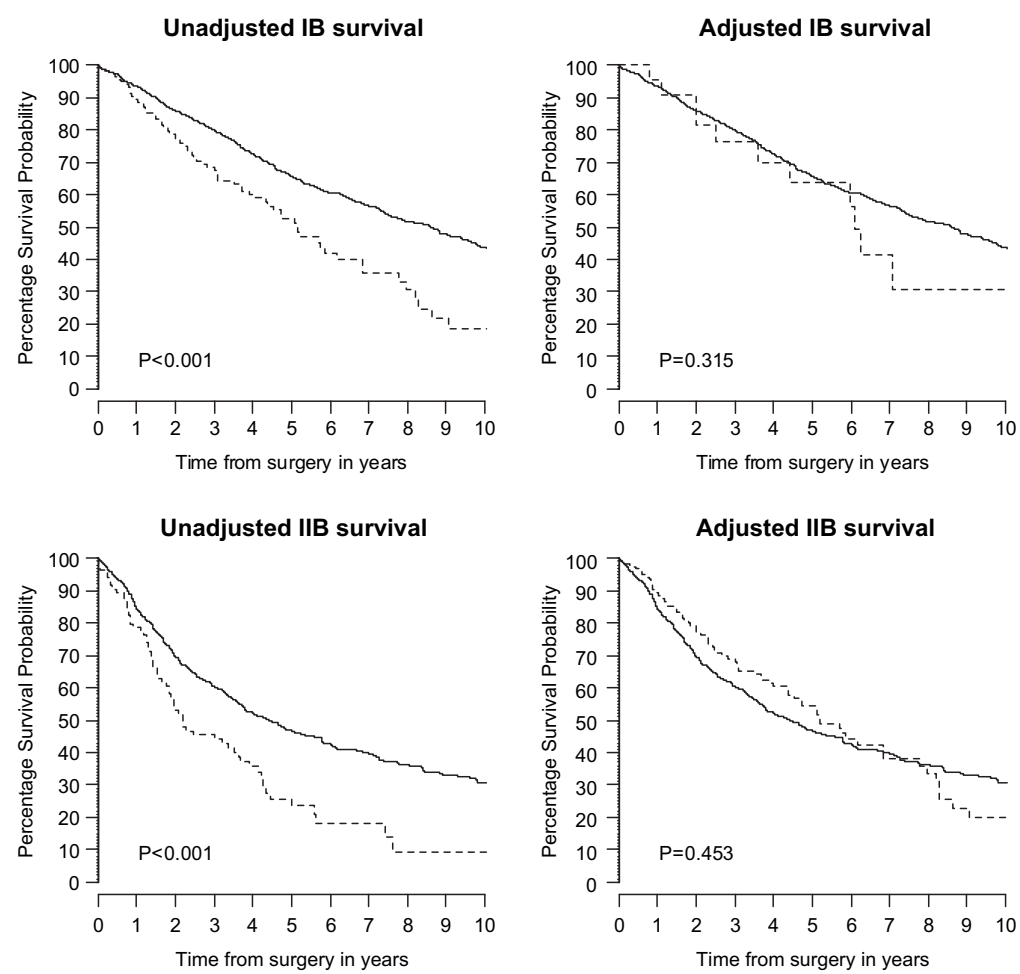

FIGURE 2. Survival by pleural lavage cytology (PLC) status with adjusted T stage for patients with positive PLC in stage I to II. Solid lines are patients with negative PLC; dashed lines are patients with positive PLC.
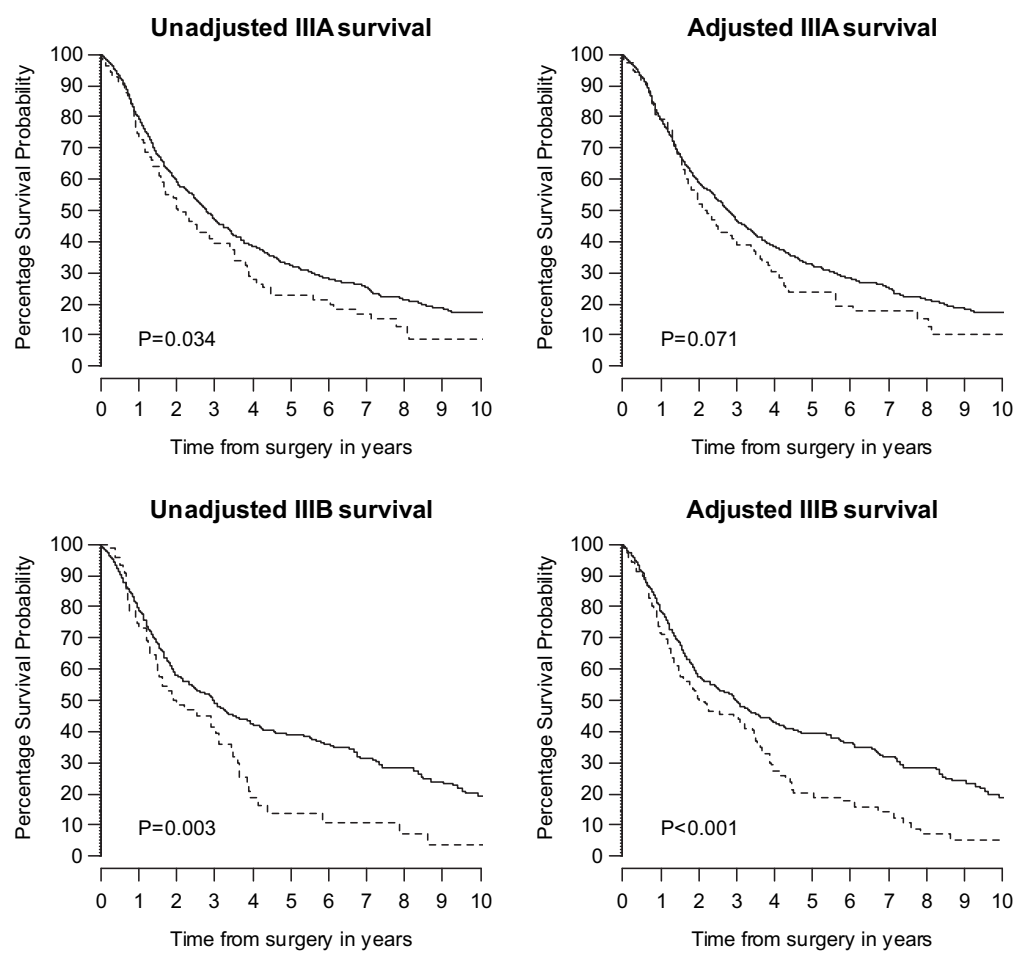

FIGURE 3. Survival by pleural lavage cytology (PLC) status with adjusted T stage for patients with positive PLC in stage III. Solid lines are patients with negative PLC; dashed lines are patients with positive PLC. 
the estimates would not be significantly altered if data were submitted by all centers that published on this topic.

\section{CONCLUSIONS}

PLC should be considered in all patients with early stage lung cancer suitable for resection. A positive result is an independent predictor of adverse survival and carries a prognosis that suggests it may be appropriate to upstage patients by 1 T category.

\section{References}

1. Kondo H, Naruke T, Tsuchiya R, Goya T, Suemasu K, Yamagishi K, et al. Pleural lavage cytology immediately after thoracotomy as a prognostic factor for patients with lung cancer. Jpn J Cancer Res. 1989;80:233-7.

2. Hillerdal G, Dernevik L, Almgren SO, Kling PA, Gustafsson G. Prognostic value of malignant cells in pleural lavage at thoracotomy for bronchial carcinoma. Lung Cancer. 1998;21:47-52.

3. Lim E, Ali A, Theodorou P, Nicholson AG, Ladas G, Goldstraw P. Intraoperative pleural lavage cytology is an independent prognostic indicator for staging nonsmall cell lung cancer. J Thorac Cardiovasc Surg. 2004;127:1113-8.

4. Mountain CF. Revisions in the International System for Staging Lung Cancer. Chest. 1997;111:1710-7.

5. Arnau Obrer A, Canto Armengod A, Martin Diaz E, Navarro Ibanez R, Ramon Capilla M, Garcia Aguado R, Martorell Cebollada M. [Prognostic value of positive cytology found in pleural lavage of patients with cancer of the lung. Prospective study]. Arch Bronconeumol. 1996;32:321-6.

6. Buhr J, Berghauser KH, Gonner S, Kelm C, Burkhardt EA, Padberg WM. The prognostic significance of tumor cell detection in intraoperative pleural lavage and lung tissue cultures for patients with lung cancer. J Thorac Cardiovasc Surg. 1997;113:683-90.

7. Buhr J, Berghauser KH, Gonner S, Schaffer R, Padberg WM. [Intrapulmonary tumor cell dissemination and intraoperative pleural lavage as prognostic factors in bronchial carcinoma]. Zentralbl Chir. 1996;121:90-5.

8. Buhr J, Berghauser KH, Gonner S, Schaffer R, Padberg WM. [Intrapulmonary tumor cell spread and intraoperative pleural lavage as prognostic factors in bronchial carcinoma?]. Langenbecks Arch Chir Suppl Kongressbd. 1996;113: 798-804.

9. Buhr J, Berghauser KH, Morr H, Dobroschke J, Ebner HJ. Tumor cells in intraoperative pleural lavage. An indicator for the poor prognosis of bronchogenic carcinoma. Cancer. 1990;65:1801-4.

10. Dresler CM, Fratelli C, Babb J. Prognostic value of positive pleural lavage in patients with lung cancer resection. Ann Thorac Surg. 1999;67:1435-9.

11. Eagan RT, Bernatz PE, Payne WS, Pairolero PC, Williams DE, Goellner JR, Piehler JM. Pleural lavage after pulmonary resection for bronchogenic carcinoma. J Thorac Cardiovasc Surg. 1984;88:1000-3.

12. Enatsu S, Yoshida J, Yokose T, Nishimura M, Nishiwaki Y, Shirakusa T, Nagai K. Pleural lavage cytology before and after lung resection in non-small cell lung cancer patients. Ann Thorac Surg. 2006;81:298-304.

13. Higashiyama M, Doi O, Kodama K, Yokouchi H, Tateishi R, Horai T, et al. Pleural lavage cytology immediately after thoracotomy and before closure of the thoracic cavity for lung cancer without pleural effusion and dissemination: clinicopathologic and prognostic analysis. Ann Surg Oncol. 1997;4:409-15.

14. Higashiyama M, Kodama K, Takami K, Higaki N, Nakayama T, Yokouchi H. Intraoperative lavage cytologic analysis of surgical margins in patients undergoing limited surgery for lung cancer. J Thorac Cardiovasc Surg. 2003;125:101-7.

15. Higashiyama M, Kodama K, Yokouchi H, Takami K, Nakayama T, Horai T. Clinical value of pleural lavage cytological positivity in lung cancer patients without intrao- perative malignant pleuritis. Recurrent pattern based on semiquantitative analysis of tumor cells in pleural lavage. Jpn J Thorac Cardiovasc Surg. 2000;48:611-7.

16. Hsu JY, Chen CY, Huang CM, Chiang CD. [Intraoperative pleural lavage in lung cancer patients]. J Formos Med Assoc. 1992;91(Suppl 1):S47-51.

17. Ichinose Y, Tsuchiya R, Koike T, Kuwahara O, Nakagawa K, Yamato Y, et al. Prognosis of resected non-small cell lung cancer patients with carcinomatous pleuritis of minimal disease. Lung Cancer. 2001;32:55-60.

18. Ichinose Y, Tsuchiya R, Yasumitsu T, Koike T, Yamato Y, Nakagawa K, et al. Prognosis of non-small cell lung cancer patients with positive pleural lavage cytology after a thoracotomy: results of the survey conducted by the Japan Clinical Oncology Group. Lung Cancer. 2001;31:37-41.

19. Ichinose Y, Yano T, Asoh H, Yokoyama H, Fukuyama Y, Katsuda Y. Diagnosis of visceral pleural invasion in resected lung cancer using a jet stream of saline solution. Ann Thorac Surg. 1997;64:1626-9.

20. Kjellberg SI, Dresler CM, Goldberg M. Pleural cytologies in lung cancer without pleural effusions. Ann Thorac Surg. 1997;64:941-4.

21. Kotoulas C, Lazopoulos G, Karaiskos T, Tomos P, Konstantinou M, Papamichalis G, et al. Prognostic significance of pleural lavage cytology after resection for non-small cell lung cancer. Eur J Cardiothorac Surg. 2001;20:330-4.

22. Maruyama R, Shoji F, Okamoto T, Miyamoto T, Miyake T, Nakamura T, et al. Prognostic value of visceral pleural invasion in resected non-small cell lung cancer diagnosed by using a jet stream of saline solution. J Thorac Cardiovasc Surg. 2004; 127:1587-92.

23. Nakagawa T, Okumura N, Kokado Y, Miyoshi K, Matsuoka T, Kameyama K. Clinical relevance of intraoperative pleural lavage cytology in non-small cell lung cancer. Ann Thorac Surg. 2007;83:204-8.

24. Oguzkaya F, Akcali Y, Bilgin M, Haberal A, Akgun H. Tumour cell frequency in pleural lavage in cases with stage I epidermoid lung cancer with no visceral pleural involvement. ANZ J Surg. 2005;75:300-1.

25. Okada M, Sakamoto T, Nishio W, Uchino K, Tsuboshima K, Tsubota N. Pleural lavage cytology in non-small cell lung cancer: lessons from 1000 consecutive resections. J Thorac Cardiovasc Surg. 2003;126:1911-5.

26. Okada M, Tsubota N, Yoshimura M, Miyamoto Y, Maniwa Y. Role of pleural lavage cytology before resection for primary lung carcinoma. Ann Surg. 1999;229: 579-84

27. Pavia R, Mule V, Angio L, Monaco F, Smedile F, Fabiano G, et al. [Intraoperative pleural lavage for restaging of bronchogenic carcinoma]. Minerva Chir. 2003;58: $67-9$.

28. Riquet M, Badoual C, Le Pimpec Barthes F, Lhote FM, Souilamas R, Hubsch JP, Danel C. Visceral pleura invasion and pleural lavage tumor cytology by lung cancer: a prospective appraisal. Ann Thorac Surg. 2003;75: 353-5.

29. Satoh Y, Hoshi R, Ishikawa Y, Horai T, Okumura S, Nakagawa K. Recurrence patterns in patients with early stage non-small cell lung cancers undergoing positive pleural lavage cytology. Ann Thorac Surg. 2007;83:197-202.

30. Vicidomini G, Santini M, Fiorello A, Parascandolo V, Calabro B, Pastore V. Intraoperative pleural lavage: is it a valid prognostic factor in lung cancer? Ann Thorac Surg. 2005;79:254-7.

31. Kondo H, Asamura H, Suemasu K, Goya T, Tsuchiya R, Naruke T, et al. Prognostic significance of pleural lavage cytology immediately after thoracotomy in patients with lung cancer. J Thorac Cardiovasc Surg. 1993; 106:1092-7.

32. Okumura M, Ohshima S, Kotake Y, Morino H, Kikui M, Yasumitsu T. Intraoperative pleural lavage cytology in lung cancer patients. Ann Thorac Surg. 1991;51: 599-604.

33. Goldstraw P, Crowley J, Chansky K, Giroux DJ, Groome PA, Rami-Porta R, et al. The IASLC Lung Cancer Staging Project: proposals for the revision of the TNM stage groupings in the forthcoming (seventh) edition of the TNM classification of malignant tumours. J Thorac Oncol. 2007;2:706-14.

34. Hermanek P, Hutter RV, Sobin LH, Wittekind C, International Union Against Cancer. Classification of isolated tumor cells and micrometastasis. Cancer. 1999;86:2668-73. 